Journal of Educational Method and Technology Vol. 2 No. 2, Agustus 2019

P-ISSN 2622-8459 E-ISSN 2622-8467

http://ejournal.unima.ac.id/index.php/jemtec

\title{
Student Satisfaction Level on Academic and Administrative Services in FMIPA Universitas Negeri Manado
}

\author{
D D W Kamagi ${ }^{1}$ \\ ${ }^{1}$ Universitas Negeri Manado, Indonesia \\ corresponding author: ${ }^{1}$ deckykamagi@unima.ac.id
}

\begin{abstract}
Student satisfaction as users of academic and administrative services has been evaluated to find out the extent of service delivery that has been carried out by the academic and administrative work units of the Faculty of Mathematics and Natural Sciences, Universitas Negeri Manado. The level of student satisfaction with academic and administrative services has been measured using a linkert scale, and analyzed using the distribution of scores, then presented and served in tables or diagrams. Measuring the level of satisfaction of students to academic and administrative services covering six aspects, including tangibles, responsiveness, reliability, empathy, assurance and information systems. The six aspects are outlined in a question sheet with each aspect consisting of several question / statement items with the same score scale. Question points for all aspects of the assessment consisted of 42 items. The number of respondents amounted to 265 respondents. The measurement data is completely re-converted to get the level of student satisfaction with five categories, namely dissatisfied, less satisfied, quite satisfied, satisfied and very satisfied. The measurement results show that the level of student satisfaction with all aspects of academic and administrative services is $5.66 \%$ very satisfied, $23.02 \%$ satisfied, $38.11 \%$ quite satisfied, $24.91 \%$ less satisfied and $8.30 \%$ dissatisfied. While the level of student satisfaction with academic and administrative services for each aspect of service shows that only tangibles aspects are the percentage of satisfaction below $50 \%$
\end{abstract}

Keywords: Satisfaction; Academic and Administrative Services; FMIPA Students

\section{Introduction}

Based on Law No. 12 of 2012, on Higher Education, it has been established that education is a conscious and planned effort to create an atmosphere of learning and learning process so that students actively develop their potential to have spiritual strength, self-control, personality, intelligence, noble character, and skills which is needed by himself, society, nation and state. In addition, it has also been determined that tertiary education institutions carry out tertiary education, which is the level of education after secondary education which includes diploma programs, 
Journal of Educational Method and Technology Vol. 2 No. 2, Agustus 2019

P-ISSN 2622-8459 E-ISSN 2622-8467

http://ejournal.unima.ac.id/index.php/jemtec

undergraduate programs, master programs, doctoral programs and professional programs, and specialist programs, which are organized by universities based on Indonesian culture. Higher Education functions (a) develops capabilities and shapes the dignified character and civilization of the nation in the context of intellectual life of the nation; (b) developing an innovative, responsive, creative, ingenious, competitive, and cooperative Academic Community through the implementation of tridharma; and (c) developing science and technology by observing and applying humanities values. Higher education aims to (a) develop the potential of students to become human beings who believe and cautious in The Almighty God and have noble, healthy, knowledgeable, capable, creative, independent, skilled, competent, and cultured for the benefit of the nation; (b) the production of graduates who master the branches of science and / or technology to meet national interests and increase national competitiveness; (c) the production of science and technology through research that pays attention to and applies the value of the humanities to benefit the progress of the nation, as well as the progress of civilization and the well-being of humanity; and (d) the realization of community service based on reasoning and research work that is useful in advancing public welfare and intellectual life of the nation.

In connection with the mandate of the Act, students as students in higher education are entitled to receive services according to their talents, interests, potential and abilities. Therefore tertiary education institutions as providers of higher education are required to provide educational services that are in line with the quality standards of service to students. The level of success of services to students is closely related to the level of satisfaction with meeting the needs of students in activities on campus. Students who are satisfied with the service can be the main capital to compete because it produces utterances with positive words, retention and loyalty (Arambewela and Hall, 2009). Academic and administrative services are services provided to students in the context of achieving academic goals, therefore academic services should have a relatively large proportion of services in other academic activities. Quality academic services will have a domino effect, in addition that students finishing their studies on time, they will also form a mutually beneficial bond with the institution, indirectly involved with promotion and imaging. Universities as a form of tertiary education are service providers in the form of graduates, therefore they must provide services according to established quality standards, so as to provide guarantees in the competition and trust of stakeholders. The quality of universities and study programs in Indonesia is currently not at an ideal condition. The difference in the quality of higher education can be seen from the results of higher education accreditation and study programs, out of 4,472 universities in Indonesia there are currently only 50 higher education institutions that have A accreditation and 2,512 A accredited study programs (12\% of 20,254 accredited study programs) (Ministry of Research and Higher Education, 2017). Currently there are 124 State Universities (PT), 3,127 Private Universities, 175 Ministry / Institution Universities, 968 PTAs, and 78 PTAN (PDDikti Data, March $11,2017)$. Based on this data, BAN-PT shows that only 1,131 are accredited with the details of 50 universities having accreditation A (4\%), 345 universities accredited B (31\%), and 736 universities accredited $C(65 \%)$, and the remaining 3,340 are not accredited. There are 26,672 study programs (PDDikti, 2017) with a total of 20,254 
accredited study programs with details of number of study programs with A accreditation of 2,512 (12\%), B accreditation of 9,922 (49\%), and C accreditation of 7,820 (39\%), in fact there are many non-accredited study programs (BAN-PT, 2017). These data indicate that the quality of most of the tertiary institutions and study programs is still far from what is expected.

Related to the quality of academic and administrative services in the FMIPA work unit of the Universitas Negeri Manado, until now there is no fact about the level of student satisfaction with these services, even though the level of student satisfaction with academic and administrative services has a positive correlation (I Nyoman Rinala, et al, 2013; Susanto, H., 2014), which can encourage students to finish college on time. In addition, the results of this study can be used as evaluation material to encourage the achievement of service quality standards

\section{Materials and Methods \\ Time and place}

This research was conducted in June-December (odd semester / academic year 2017/2018) and located in the work unit of the Faculty of Mathematics and Natural Sciences, Universitas Negeri Manado in Tondano.

\section{Population and Sample}

The population of this research is the active students of the class of 20142017. The sampling technique used was proportionate stratified random sampling, where each department / study program per year was represented by several students who were taken at random. The minimum number of sample members is determined based on Supranto, (2006) using the following formula:

$$
n=\frac{N}{N(\mathrm{~d})^{2}+1}
$$

where, $\mathrm{n}=$ number of sample members

$\mathrm{N}=$ total population

$\mathrm{d}=$ percentage tolerance of accuracy of sampling error

\section{Data collection technique}

Data is collected through the use of a questionnaire with multiple answer choices and with an attitude scale that contains attitude statements, which is a statement of attitude about an object. Questionnaire to measure the level of satisfaction of students to academic services and administrative compiled based on five factors that determine the quality of service according to Kotler and Armstrong (2012) which includes: (1) tangible, (2) reliability,(3) responsiveness, (4) assurance, (5) empathy and (6) information systems. The Likert scale is used to measure attitude statements with four categories of answers as shown in Table 1. 
Journal of Educational Method and Technology Vol. 2 No. 2, Agustus 2019

P-ISSN 2622-8459 E-ISSN 2622-8467

http://ejournal.unima.ac.id/index.php/jemtec

Table 1. Score Questionnaire Answers About Service Satisfaction

\begin{tabular}{lc}
\hline \multicolumn{1}{c}{ Category } & Answer Score \\
\hline Very satisfied & 5 \\
Satisfied & 4 \\
Quite satisfied & 3 \\
Not satisfied & 2 \\
Very Dissatisfied & 1 \\
\hline
\end{tabular}

The measurement data is completely re-converted to get the level of student satisfaction with five categories, namely dissatisfied, less satisfied, quite satisfied, satisfied and very satisfied. Data conversion to obtain the satisfaction level category is grouped based on frequency distribution with five different interval classes where each interval class is determined based on the formula $\geq X=$ average $+(1.5 \times$ standard deviation) for the interval class with the very satisfied category and $\leq \mathrm{X}=$ average - $(1.5 \times$ standard deviation $)$ for interval classes with dissatisfied categories. For interval classes with satisfied categories, quite satisfied and less satisfied are determined by determining the lower class boundary of each interval class by dividing 3 results from the difference between the largest class limit and the smallest class limit.

\section{Data analysis}

Data analysis using descriptive statistics is data that is processed and then presented in tables and graphs. The average value of the data is presented in a table to obtain a description of all aspects measured. Graphs are presented to obtain ease of understanding, analysis and conclusions.

\section{Results and Discussion Measurement Description}

The level of student satisfaction with academic and administrative services has been measured using a linkert scale, and analyzed using the distribution of scores, then presented and served in tables or diagrams. Measuring the level of satisfaction of students to academic and administrative services covering six aspects, including tangibles, responsiveness, reliability, empathy, assurance and information systems. The six aspects are outlined in a questionnaire with each aspect consisting of several questions / statements with the same statement. The questions / statements for any aspects of the assessment are: aspects of tangibles 8 items, responsiveness 5 items, reliability 11 items, empathy 7 items, assurance 6 items and information system 5 items. Thus the scoring ratings for each of the following aspects: tangibles with 8 items, the lowest score $=8$ and the highest $=40$, the aspect of responsiveness with 5 items, the lowest score $=5$ and the highest $=25$, aspects of reliability with 11 items, the lowest score $=11$ and the highest $=55$, aspects of empathy with 7 items, the lowest score $=7$ and the highest $=35$, aspects of assurance with 6 items, the lowest score $=6$ and the highest $=30$ and aspects of information systems with 5 items, the lowest score $=5$ and the highest $=25$. Since the total questions for all aspects is $=42$, mean overall, the lowest score 42 and the highest score is 210 . 
Journal of Educational Method and Technology Vol. 2 No. 2, Agustus 2019

P-ISSN 2622-8459 E-ISSN 2622-8467

http://ejournal.unima.ac.id/index.php/jemtec

\section{Description of Measurement Results}

Student satisfaction with academic and administrative services at FMIPA UNIMA has been measured by 42 question items for all aspects with a scale of 1, 2, 3,4 and 5. The statistical data of the overall level of student satisfaction with all aspects of academic and administrative services is shown in Table 2.

Table 2 . Statistical data on all aspects of academic and administrative services

\begin{tabular}{|c|c|c|c|c|c|}
\hline & $\mathrm{N}$ & Min. & Max. & Average & Std.Deviation \\
\hline & 265 & 48 & 192 & $\begin{array}{c}121,6 \\
1\end{array}$ & $26, .62$ \\
\hline $\begin{array}{l}\text { Valid } \\
\mathrm{N}\end{array}$ & 265 & & & & \\
\hline
\end{tabular}

Data conversion of all aspects of academic and administrative services into frequency distribution with five categories of student satisfaction levels is shown in Table 3.

Table 3 . Student satisfaction level categories for all aspects of academic and administrative services

\begin{tabular}{|c|c|c|c|}
\hline $\begin{array}{c}\text { Interval } \\
\text { class }\end{array}$ & Frequency & $\%$ & Category \\
\hline$\leq 83$ & 22 & 8.30 & $\begin{array}{c}\text { Not } \\
\text { satisfied }\end{array}$ \\
\hline $84-109$ & 66 & 24.91 & $\begin{array}{c}\text { Less } \\
\text { satisfied }\end{array}$ \\
\hline $110-135$ & 101 & 38.11 & $\begin{array}{c}\text { Quite } \\
\text { satisfied }\end{array}$ \\
\hline $136-161$ & 61 & 23.02 & Satisfied \\
\hline$\geq 162$ & 15 & 5.66 & $\begin{array}{c}\text { Very } \\
\text { satisfied }\end{array}$ \\
\hline amount & 265 & $100 \%$ & \\
\hline
\end{tabular}

Based on the conversion of data in the frequency distribution obtained a general description of the level of student satisfaction with academic and administrative services that is very satisfied $5.66 \%$, satisfied $23.02 \%$, quite satisfied $38.11 \%$, less satisfied $24.91 \%$ and dissatisfied $8,30 \%$ The frequency of each category of level of student satisfaction with academic and administrative services is shown in Figure 1. 


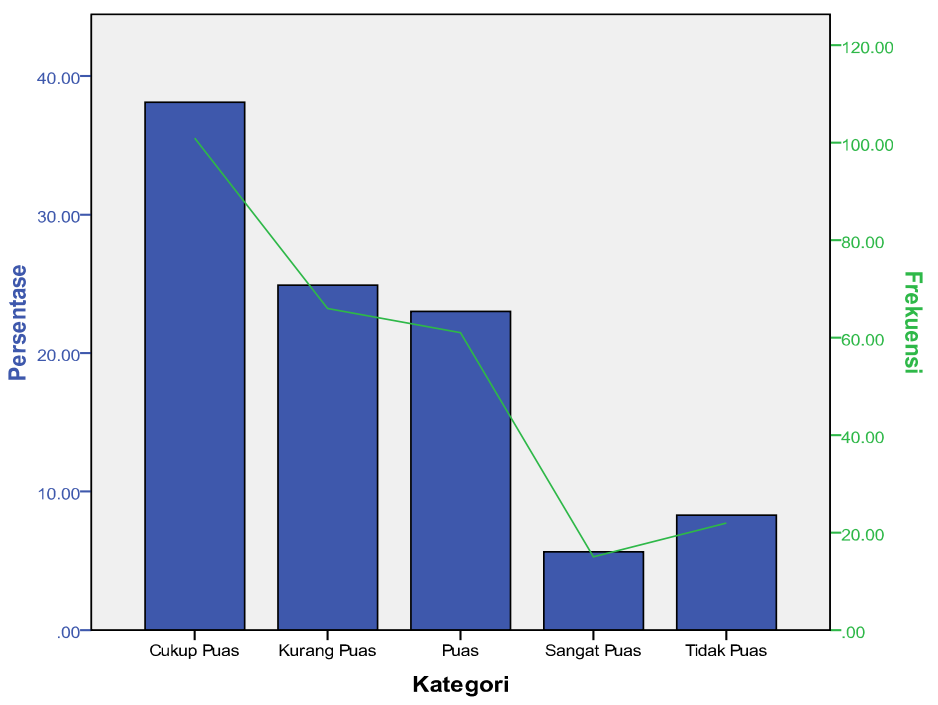

Figure 1. Percentage and frequency for each category of student satisfaction level of the academic and administrative services.

\section{Student Satisfaction Level Per Academic and Administrative Service Aspects}

The level of student satisfaction with academic and administrative services on tangibles aspects, with the lowest score of 10, the highest score of 38, an average of 20.57 and a standard deviation of 5.52. The level of student satisfaction with academic and administrative services on the aspect of reliability, with the lowest score of 11, the highest score of 55, an average of 33.61 and a standard deviation of 7.79. The level of student satisfaction with academic and administrative services in the aspect of assurances, with the lowest score of 6 , the highest score of 30, an average of 18.29 and a standard deviation of 4.92. The level of student satisfaction with academic and administrative services on the aspects of empathy, with the lowest score of 7, the highest score of 35, an average of 20.01 and a standard deviation of 5.33. The level of student satisfaction with academic and administrative services in the information system aspect, with the lowest score 5 and the highest score of 25 , an average of 14.26 and a standard deviation of 4.28. The average student satisfaction level per aspect of academic and administrative services is shown in Figure 2 . 


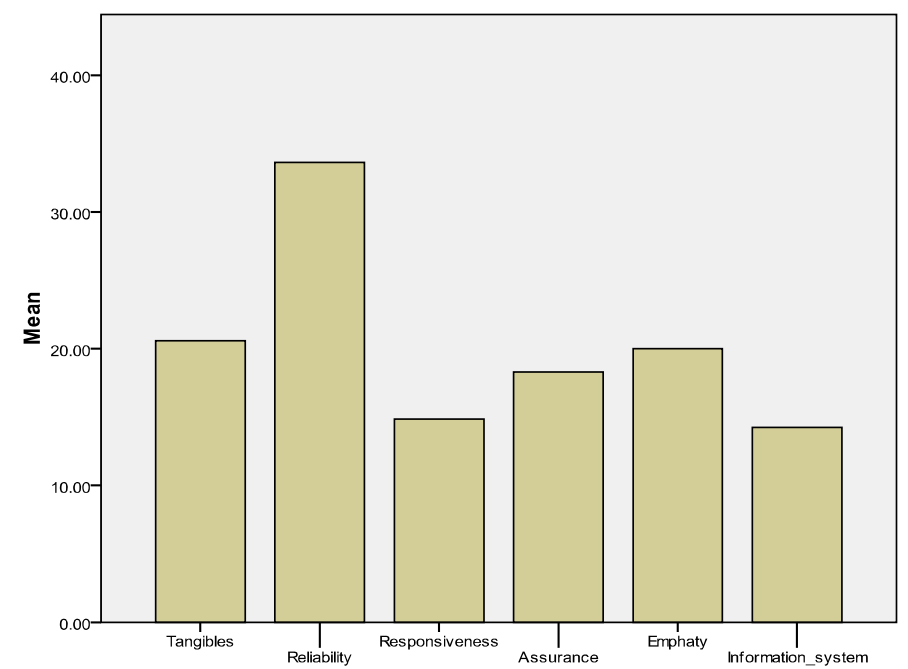

Figure 2. Chart of the average level of student satisfaction for each aspect of academic and administrative services.

\section{Tangibles aspect}

Conversion of student satisfaction level data on aspects of academic and administrative service tangibles with five categories of satisfaction levels is shown in Table 5.

Table 5. Data conversion level of student satisfaction with the services of academic and administrative on the aspects of tangibles.

\begin{tabular}{|c|c|c|c|}
\hline $\begin{array}{c}\text { Interval } \\
\text { class }\end{array}$ & Frequency & $\%$ & Category \\
\hline$<15$ & 8 & 3.02 & $\begin{array}{c}\text { Not } \\
\text { satisfied }\end{array}$ \\
\hline $16-21$ & 155 & 58.49 & $\begin{array}{c}\text { Less } \\
\text { satisfied }\end{array}$ \\
\hline $22-27$ & 64 & 24,15 & $\begin{array}{c}\text { Quite } \\
\text { satisfied }\end{array}$ \\
\hline $28-33$ & 30 & 11.32 & Satisfied \\
\hline$>34$ & 8 & 3.02 & $\begin{array}{c}\text { Very } \\
\text { satisfied }\end{array}$ \\
\hline amount & 265 & $100 \%$ & \\
\hline
\end{tabular}

The frequency and percentage of data conversion according to the level of student satisfaction on aspects of academic and administrative service tangibles are shown in Figure 3. 
http://ejournal.unima.ac.id/index.php/jemtec

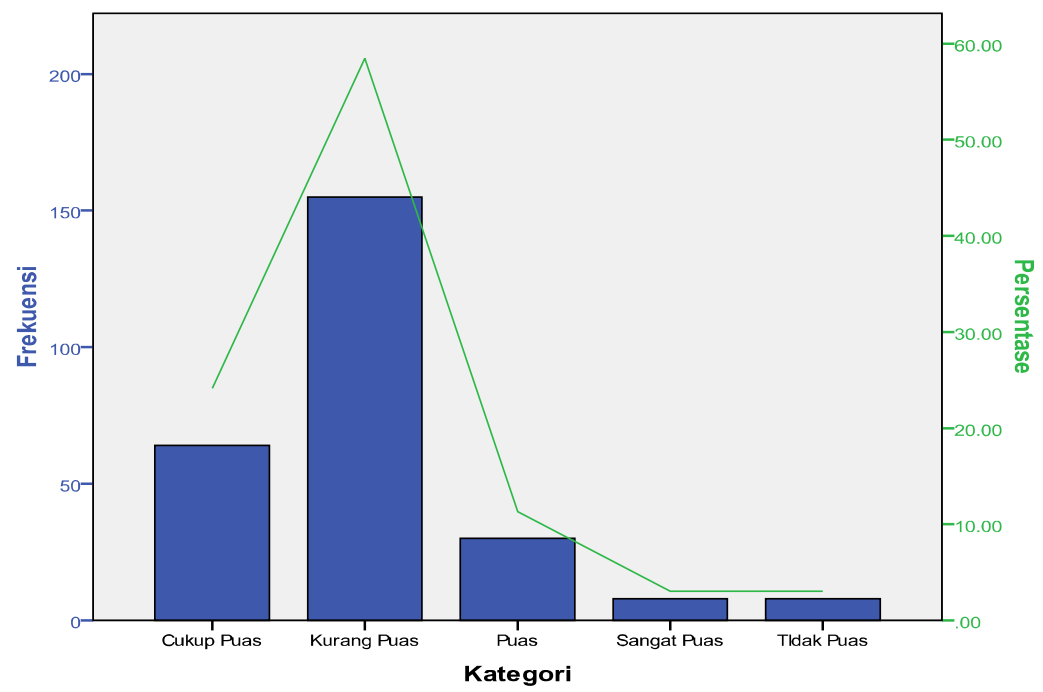

Figure 3. Frequency and percentage of student satisfaction level categories for academic and administrative services on tangibles aspects.

\section{Reliability aspects}

Conversion of student satisfaction level data on aspects of academic and administrative service reliability with five categories of student satisfaction levels is shown in Table 6.

Table 6. Conversion of student satisfaction level data on aspects of academic and administrative service reliability

\begin{tabular}{|c|c|c|c|}
\hline $\begin{array}{c}\text { Interval } \\
\text { class }\end{array}$ & Frequency & $\%$ & Category \\
\hline$<22$ & 18 & 6.79 & $\begin{array}{c}\text { Not } \\
\text { satisfied }\end{array}$ \\
\hline $23-30$ & 73 & 27.55 & $\begin{array}{c}\text { Less } \\
\text { satisfied }\end{array}$ \\
\hline $31-38$ & 112 & 42.26 & $\begin{array}{c}\text { Quite } \\
\text { satisfied }\end{array}$ \\
\hline $39-45$ & 41 & 15.47 & Satisfied \\
\hline$>46$ & 21 & 7.93 & $\begin{array}{c}\text { Very } \\
\text { satisfied }\end{array}$ \\
\hline amount & 265 & $100 \%$ & \\
\hline
\end{tabular}

The frequency and percentage of student satisfaction levels on aspects of academic and administrative service reliability are shown in Figure 4. 
http://ejournal.unima.ac.id/index.php/jemtec

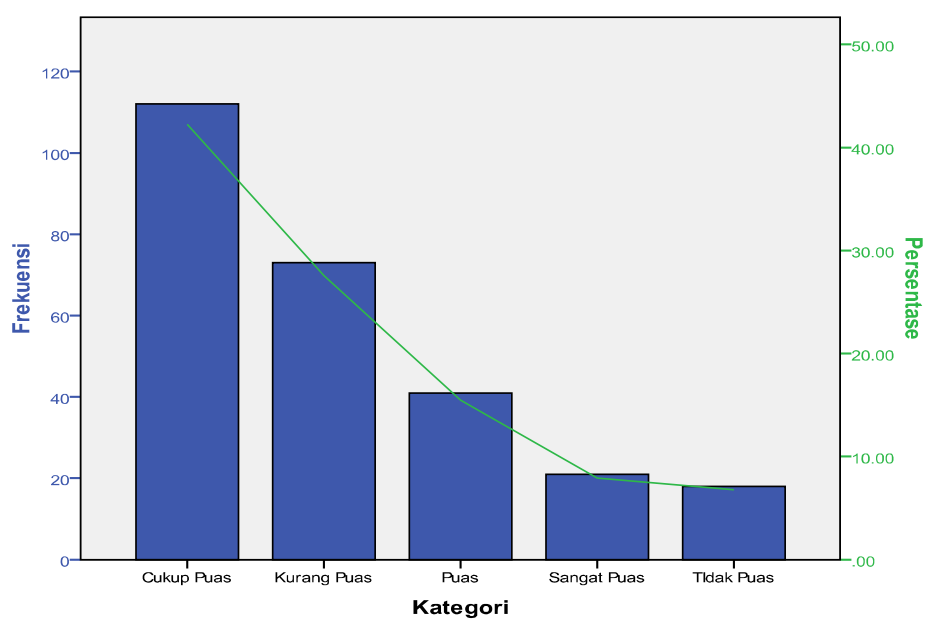

Figure 4. Frequency and percentage of student satisfaction level categories in the aspects of academic and administrative service reliability.

\section{Responsiveness aspects}

Conversion of student satisfaction level data on the responsiveness aspects of academic and administrative services with five categories of student satisfaction levels is shown in Table 7.

Table 7. Data conversion of student satisfaction levels on the responsiveness aspects of academic and administrative services

\begin{tabular}{|c|c|c|c|}
\hline $\begin{array}{c}\text { Interval } \\
\text { class }\end{array}$ & Frequency & $\%$ & Category \\
\hline$\leq 8$ & 24 & 9.06 & $\begin{array}{c}\text { Not } \\
\text { satisfied }\end{array}$ \\
\hline $9-12$ & 56 & 21.13 & $\begin{array}{c}\text { Less } \\
\text { satisfied }\end{array}$ \\
\hline $13-16$ & 96 & 36.23 & $\begin{array}{c}\text { Quite } \\
\text { satisfied }\end{array}$ \\
\hline $17-20$ & 61 & 23.02 & Satisfied \\
\hline$\geq 21$ & 28 & 10.56 & $\begin{array}{c}\text { Very } \\
\text { satisfied }\end{array}$ \\
\hline amount & 265 & $100 \%$ & \\
\hline
\end{tabular}

The frequency and percentage of categories of student satisfaction with academic and administrative services in the aspect of responsiveness are shown in Figure 5. 
http://ejournal.unima.ac.id/index.php/jemtec

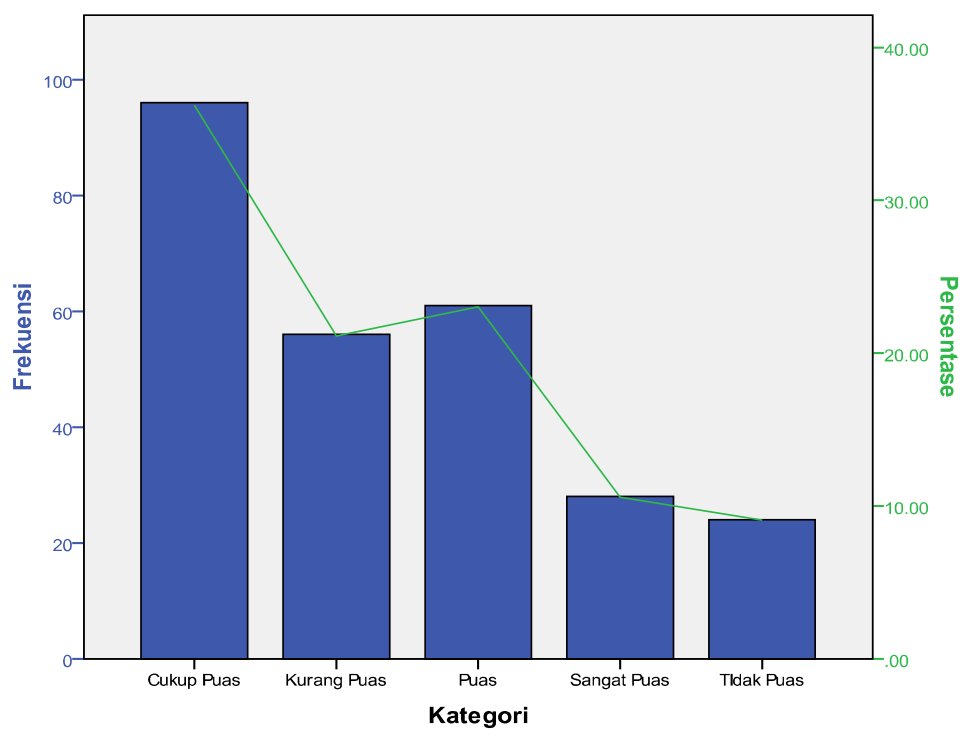

Figure 5. Frequency and percentage of student satisfaction level categories on the responsiveness aspects of academic and administrative services.

\section{Assurance aspects}

Conversion of student satisfaction level data on assurance aspects of academic and administrative services with five categories of student satisfaction levels is shown in Table 8.

Table 8. Conversion of student satisfaction level on assurance aspect of academic and administrative services.

\begin{tabular}{|c|c|c|c|}
\hline $\begin{array}{c}\text { Interval } \\
\text { class }\end{array}$ & $\begin{array}{c}\mathrm{F} \\
\text { frequency }\end{array}$ & $\%$ & Category \\
\hline$\leq 10$ & 17 & 6.41 & $\begin{array}{c}\text { Not } \\
\text { satisfied }\end{array}$ \\
\hline $11-15$ & 57 & 21.51 & $\begin{array}{c}\text { Less } \\
\text { satisfied }\end{array}$ \\
\hline $16-20$ & 104 & 39.25 & $\begin{array}{c}\text { Quite } \\
\text { satisfied }\end{array}$ \\
\hline $21-25$ & 65 & 24.53 & Satisfied \\
\hline$\geq 26$ & 22 & 8.3 & $\begin{array}{c}\text { Very } \\
\text { satisfied }\end{array}$ \\
\hline amount & 265 & $100 \%$ & \\
\hline
\end{tabular}

The frequency and percentage of each category of student satisfaction level in the aspect of academic and administrative service's assurance are shown in Figure 6. 


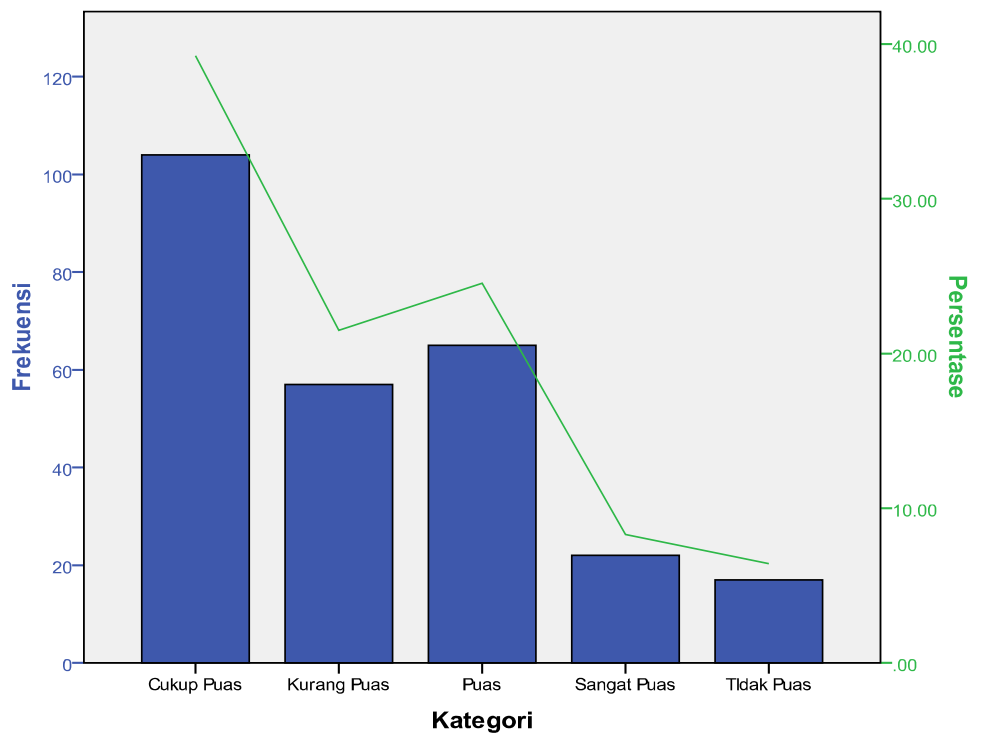

Figure 6. Frequency and percentage of student satisfaction level categories on the aspects of academic and administrative service assurance.

\section{Empathy aspect}

Conversion of student satisfaction level data on aspects of academic and administrative service empathy with five categories of student satisfaction levels is shown in Table 9.

Table 9. Data conversion of student satisfaction levels on aspects of academic and administrative service empathy.

\begin{tabular}{|c|c|c|c|}
\hline $\begin{array}{c}\text { Interval } \\
\text { class }\end{array}$ & Frequency & $\%$ & Category \\
\hline$\leq 12$ & 21 & 7.93 & $\begin{array}{c}\text { Not } \\
\text { satisfied }\end{array}$ \\
\hline $13-17$ & 64 & 24,15 & $\begin{array}{c}\text { Less } \\
\text { satisfied }\end{array}$ \\
\hline $18-22$ & 98 & 36.98 & $\begin{array}{c}\text { Quite } \\
\text { satisfied }\end{array}$ \\
\hline $23-27$ & 57 & 21.51 & Satisfied \\
\hline$\geq 28$ & 25 & 9.43 & $\begin{array}{c}\text { Very } \\
\text { satisfied }\end{array}$ \\
\hline amount & 265 & $100 \%$ & \\
\hline
\end{tabular}

The frequency and percentage of student satisfaction level categories in the aspects of academic and administrative service empathy are shown in Figure 7. 


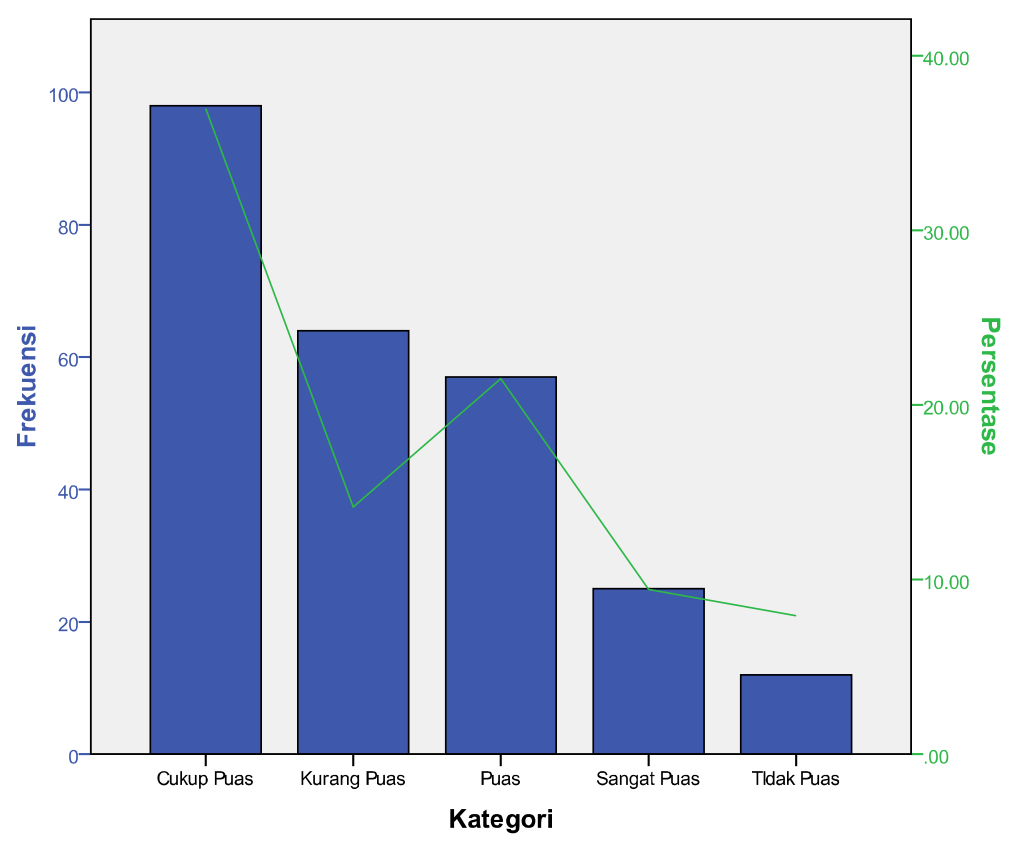

Figure 7. Frequency and percentage of student satisfaction level categories in the aspects of academic and administrative service empathy.

\section{Information system aspects}

Conversion of student satisfaction level data on aspects of academic and administrative service information systems with five categories of student satisfaction levels is shown in Table 10.

Table 10 . Conversion of student satisfaction level data on information system aspects of academic and administrative service.

\begin{tabular}{|c|c|c|c|}
\hline $\begin{array}{c}\text { Interval } \\
\text { class }\end{array}$ & Frequency & $\%$ & Category \\
\hline$\leq 8$ & 24 & 9.05 & $\begin{array}{c}\text { Not } \\
\text { satisfied }\end{array}$ \\
\hline $9-12$ & 68 & 25.67 & $\begin{array}{c}\text { Less } \\
\text { satisfied }\end{array}$ \\
\hline $13-16$ & 98 & 36.98 & $\begin{array}{c}\text { Quite } \\
\text { satisfied }\end{array}$ \\
\hline $17-20$ & 52 & 19.62 & Satisfied \\
\hline$\geq 21$ & 23 & 8.68 & $\begin{array}{c}\text { Very } \\
\text { satisfied }\end{array}$ \\
\hline amount & 265 & $100 \%$ & \\
\hline
\end{tabular}

The frequency and percentage of student satisfaction level categories in the academic and administrative service information system aspects are shown in Figure 8. 


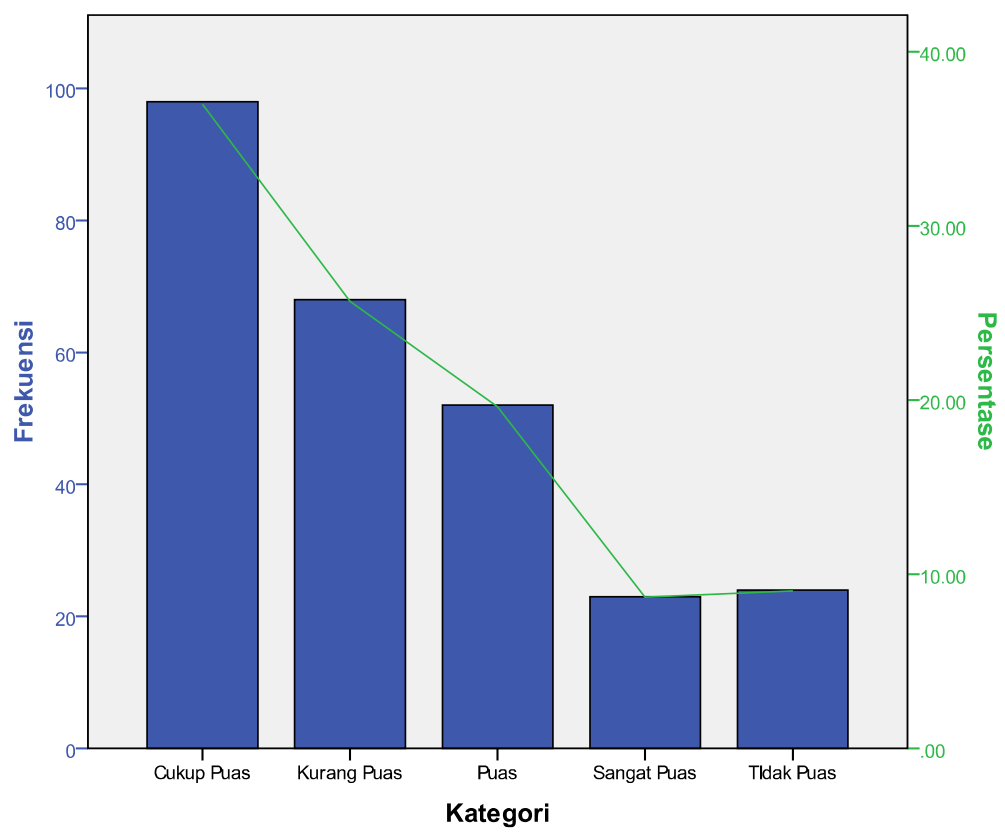

Figure 8 . Frequency and percentage of student satisfaction level categories on the information system aspects of academic and administrative services.

\section{Discussion}

\section{Overall Evaluation of Academic and Administrative Service Aspects}

The results of measurements of the level of student satisfaction with academic and administrative services in the work unit of the Faculty of Mathematics and Natural Sciences, on all aspects of academic and administrative services showed $5.66 \%$ very satisfied, $23.02 \%$ satisfied, $38.11 \%$ quite satisfied, $24,91 \%$ less satisfied and 8.30 dissatisfied. Thus in general it can be said that academic and administrative services in the FMIPA work unit are not bad but also not yet optimal, this is indicated by $33.21 \%$ of students who are not satisfied with the service but students who are quite satisfied to the point of satisfaction are quite large ie $66.79 \%$. Handayani et al ., (2003) states that to achieve a high level of satisfaction in service requires an understanding of what is desired by consumers. Although the level of consumer satisfaction is individual, which depends on the values adopted and applies, but the level of satisfaction is the level of one's feelings when measuring the results of a comparison of what he expected and what he has received (Kotler, 2000). This means that the smaller the difference between what is expected and what is received by consumers, the higher the level of customer satisfaction with services. Related to this, it indicates that student satisfaction with academic and administrative services depends on the quality of service they expect and what they receive. Academic and administrative services are said to be of high quality if the service is equal or even exceeds student expectations. Quality of service on students has a positive effect on student satisfaction (Indah , Elza Putri 2012; I Nyoman Rinala, et al., 2013 ; Aris Fita Bayu Apriliana, et al., 2014 ). More emphaticly Effiyadi (2008); I Nyoman Rinala, et al., 2013 , stated that aspects of academic services to students simultaneously had a positive effect on student satisfaction. Furthermore it is said 
Journal of Educational Method and Technology Vol. 2 No. 2, Agustus 2019

P-ISSN 2622-8459 E-ISSN 2622-8467

http://ejournal.unima.ac.id/index.php/jemtec

that service quality has an influence on satisfaction, and satisfaction subsequently affects student loyalty. Thus, improving the quality of academic services will increase student satisfaction, and will further affect student loyalty.

\section{Evaluation of Each Academic and Administrative Service Aspect}

The results of measurements of the level of student satisfaction with each of the aspects of academic and administrative services show that in the tangibles aspect of the dissatisfied to less satisfied category of $61.51 \%$, quite satisfied until very satisfied $38.49 \%$, the reliability aspect with the dissatisfied category until less satisfied at $34.34 \%$, quite satisfied until very satisfied $65.66 \%$, responsiveness aspects with the category of dissatisfied to less satisfied at $30.19 \%$, satisfied until very satisfied $69.81 \%$, assurance aspects with the category of dissatisfied to less satisfied is $27.92 \%$, quite satisfied until very satisfied $72.08 \%$, empathy aspects with the dissatisfied category until less satisfied are $32.08 \%$, quite satisfied until very satisfied $67.92 \%$, and aspects of the information system with the category of dissatisfied to less satisfied by $34.72 \%$, quite satisfied to $65.28 \%$ very satisfied. Based on the results of these measurements except aspects of tangibles, obtained the fact that the level of student satisfaction with each aspect of academic and administrative services is sufficient to meet the desires of students. In this connection Srinadi et al. (2008), states that the quality of service aspects tangibles, reliability, responsiveness, assurance and empathy have positive effects and simultaneously affect student satisfaction.

The results of the evaluation of several aspects of academic and administrative services, the aspect that still do not meet the expectations of students is tangibles aspect, while other aspects are sufficient to meet student desires. The tangibles aspect relates to education and learning facilities and infrastructure variables: lecture halls, lecture aids, learning media, laboratories, governance of space use, libraries, availability of reference books, toilet facilities, worship facilities, and internet networks. It has been stated before, that aspects of the service simultaneously affect student satisfaction so that service quality improvement must be carried out simultaneously as well. If the quality of service in tangibles aspects is addressed, other aspects will be affected, or vice versa. Implementation of education should look at the quality of service. Educational activities are not only oriented towards the final result the educational process, but also through the proof of accountability includes quality assurance, quality control, and quality improvement.

\section{Conclusions And Suggestions \\ Conclusion}

The level of student satisfaction with academic and administrative services for all aspects of service is very satisfied 5.66\%, 23.02\% satisfied, $38.11 \%$ quite satisfied, $24.91 \%$ less satisfied and $8.30 \%$ dissatisfied, while for each aspect includes aspects of tangibles shows $3.02 \%$ dissatisfied categories, $61.51 \%$ less satisfied, $24.15 \%$ quite satisfied, $11.32 \%$ satisfied, and $3.02 \%$ very satisfied. The reliability aspect shows that the dissatisfied category is $6.79 \%$, less satisfied $27.55 \%$, quite satisfied $42.26 \%$, satisfied $1.47 \%$, and very satisfied $7.93 \%$. Responsiveness assumptions shows $9.06 \%$ dissatisfied categories, $21.13 \%$ less satisfied, $26.23 \%$ quite satisfied, $23.02 \%$ satisfied, and $10.56 \%$ very satisfied. The assurance aspect 
Journal of Educational Method and Technology Vol. 2 No. 2, Agustus 2019

P-ISSN 2622-8459 E-ISSN 2622-8467

http://ejournal.unima.ac.id/index.php/jemtec

shows that the category of dissatisfaction is $6.41 \%$, less than $21.51 \%$, quite satisfied $39.25 \%$, satisfied $24.53 \%$, and very satisfied $8.3 \%$. Empathy aspect shows that the category of dissatisfaction is $7.93 \%$, unsatisfied $24.15 \%$, quite satisfied $36.98 \%$, satisfied $21.51 \%$, and very satisfied $9.43 \%$. Information system aspects showed that the category of dissatisfaction was $9.05 \%$, unsatisfied $25.67 \%$, quite satisfied $36.98 \%$, satisfied $19.62 \%$, and very satisfied $8.68 \%$.

\section{Suggestion}

In general, the level of satisfaction of FMIPA students towards academic and administrative services in general is quite high. This shows that the academic and administrative services in the FMIPA work unit are quite good, but need to be improved again, especially in the tangibles aspect, which is related to the provision of physical facilities and infrastructure and supporting learning.

\section{References}

Aris Fita Bayu Apriliana, Sigit Santoso, Sri Sumaryati, 2014. Pengaruh Kualitas Pelayanan Akademik terhadap Kepuasan Mahasiswa BKK Pendidikan Akuntansi Program Studi Pendidikan Ekonomi Fakultas Keguruan dan Ilmu Pendidikan Universitas Sebelas Maret Surakarta. Jupe UNS, Vol 2, No 3, Hal 211-223. Juni, 2014.

Budi, Santoso. 2008. Upaya Peningkatan Manajemen Perguruan Tinggi Swasta agar dapat Bersaing di Era Global. Materi Dies Reader Universitas PGRI Yogyakarta. UPY Yogyakarta.

Detha, Rintiansyah Putri. 2012. Kepuasan Warga Sekolah Terhadap Implementasi Sistem Manajemen Mutu Dalam Hal Pelayanan Di SMK N 2 Yogyakarta. Skripsi. Universitas Negeri Yogyakarta.

Effiyaldi. (2008). Analisis kualitas pelayanan terhadap kepuasan mahasiswa pada perpustakaan STIKOM Dinamika Bangsa. Jurnal Media Akademik, vol 2(1): 68-76.

Handayani, R, Yermias T. K., \& Ratminto. (2003). Analisis kepuasan pemakai terhadap pelayanan perpustakaan nasional provinsi daerah istimewa Yogyakarta. Sosiosains, vol 17(2), April 2003. Pasca Sarjana Fisipol UGM, Yogyakarta.

I Nyoman Rinala, I Made Yudana, I Nyoman Natajaya, 2013. Pengaruh Kualitas Pelayanan Akademik Terhadap Kepuasan Dan Loyalitas Mahasiswa Pada Sekolah Tinggi Pariwisata Nusa Dua Bali, e-Journal Program Pascasarjana Universitas Pendidikan Ganesha Program Studi Administrasi Pendidikan. Volume 4.

Indah, Elza Putri. 2012. Tanggapan Mahasiswa Terhadap Kualitas Pelayanan Akademik Di Fakultas Ilmu Sosial Dan Ilmu Politik Universitas Hasanuddin. Skripsi. Universitas Hasanuddin.

Kotler, P. dan Armstrong G., 2012. Principles of Marketing 14th Edition. England: Pearson Education Limited

Srinadi, I Gusti Ayu Made \& Desak Putu Eka Nilakusmawati. (2008). Faktorfaktor penentu kepuasan mahasiswa terhadap pelayanan fakultas sebagai 
Journal of Educational Method and Technology Vol. 2 No. 2, Agustus 2019

P-ISSN 2622-8459 E-ISSN 2622-8467

http://ejournal.unima.ac.id/index.php/jemtec

lembaga pendidikan (studi kasus FMIPA Universitas Udayana). Cakrawala pendidikan Tahun XXVII No 3, Denpasar 